\title{
COMMUNAL HYGIENE OF A PART OF THE URBAN AREA OF REPUBLIC OF SRPSKA
}

DOI: http://dx.doi.org/10.18509/GBP.2015.36

UDC: 628.4(497.6)

\author{
Dr Čedomir Crnogorac, \\ PhD, Dr Vesna Rajčević \\ Faculty of Sciences, University of Banja Luka
}

\begin{abstract}
The city, that is, the urban area represents a large, compact settlement where majority of people are employed in secondary and tertiary industries, working not only for themselves but also for their fellow citizens. Apart from the functions defined by predominant industries, the city also features the administrative, educational, health and other functions as well. The more urban the area, the more influential it is concerning the surrounding environment. A huge concentration of people on a relatively small area brings with it all the conceivable inconveniences of life there are. New elements of life in the city lead to the pollution of geocomponents and changes in habits of living. Not only does a modern city takes up a wider area on the ground, but also reaches towards the sky to a great extent. Due to the height of buildings, the microclimate in the city changes to the point that many cities are nowadays referred to as 'heat islands'. When the city development is concerned, there are three basic directions, according to contemporary scientific theories and research: technocratic (the idea of unlimited growth), alarming (the idea of 'zero growth') and various balanced concepts of "viable development of the environment. The notion of the city gives birth to the notion of urbanization, which implies the processes of numeric, demographic, functional and physiognomic development of the city on one hand and the process of spreading the idea of city life style on the areas beyond the city limits on the other. The environment issues are perceived as an integral part of economic, technological and social development. Wherever that process was not consistent with the legal norms and development standards, there are numerous harmful consequences of urbanization: overpopulation issues, traffic jams, waste disposal, dislocation of 'dirty industries', water supply of households and businesses etc. The issue of communal hygiene in urban areas is comprehensive and comprises all the factors of this field: water, land, waste matters, air, climate, water, air and land pollution, radiation, noise pollution, vibrations, ultrasound etc. The aim of the research is to determine the extent to which the standards of communal hygiene are applied in certain urban areas of Republic of Srpska, as well as to determine to what extent citizens are satisfied with the concern local authorities and the authorities of the Republic of Srpska show when dealing with topical communal problems. In addition, the aim of the research is to show the level of familiarity of urban people with the local, entity and international legislation. In the paper are used the methods of analysis and synthesis in geoecology, statistical method, classification as a method in researching into the environment and a questionnaire.
\end{abstract}

Key words: the city, urban development of cities, communal hygiene, standards and norms of communal hygiene of cities. 


\section{INTRODUCTION}

Urbanisation mainstream. The most active focuses between nature and society are urban areas. The survival of settlements, human population and environment in general depends on the extent to which the relation between urban and natural environment will be successfully balanced. The concept of urbanisation is defined in different ways. According to urban geographers, urbanisation in a narrow sense is deemed the process of concentrating population in large cities, while in a broader sense urbanisation means the spatial spreading of urban structures towards the suburb and inclusion of their surroundings into urban settlements. Given the aforesaid, it seems that urbanisation represents the spatial and demographic development of cities, spreading of the urban way of life and the most significant spatial category of the mutuality of society and natural environment. The main elements of a settlement in hierarchical sense are urban systems, towns, suburbs, villages, hamlets, traffic junctions and the like. All these represent mutually and spatially functional relation as well as a connection with natural environment. The urban system is considered a system, relations and connections enabling interactions in circulation of people, goods and information.

Urbanisation is a very old phenomenon. People used to live in towns thousands of years before development of urban hubs took place. However, the city as we know it is a relatively new phenomenon. A city i.e. urban settlement is a compact large settlement the majority population of which are employed in the secondary and tertiary industries. The functional and gravitational influence of cities on the surrounding area is in correlation with the increase in urbanisation process. A city is rightfully said to be the cradle of civilization. The urban development is encumbered by numerous problems. Urbanisation as a realistic process is accompanied by some other features. Parallel to a number of social and economic problems, urbanisation has brought out a complex of environmental and often health problems which sometimes jeopardize the survival of urban population. These problems can be grouped in pairs e.g. clean water - polluted water, clean air polluted air $(1,37)$

The consequences of a rapid and often unreasonable urbanisation in the world and Republic of Srpska are intense and diverse. Urbanisation has emphasised an unreasonable use of a limited space, especially arable land, which is quite limited in area. Urbanised areas and industrial towns in some parts of Republic of Srpska considerably endanger the quality of environment and its components - air, water (ground and surface one), arable land, plant and animal species. Besides, an uncontrolled growth of cities and urban systems, both horizontally and vertically, have a substantial influence on a change in microclimate and other natural values and also leads to dehumanisation of life, different types of anxiety and other sociological and psychological disorders $(3,99)$.

A way must be found for a slower growth rate of cities and increase in the quality of environment accompanied with a rational utilisation of all natural and human values. The development needs to be fostered of smaller urban settlements, in which it is easier to build, work and more pleasant to live. The polycentric development should in any case replace the monocentric development. A reorientation in the economic policy as well as faster agricultural development is necessary, which would contribute to the development of rural areas and prevent a part of population from migrating i.e. reduce the demographic pressure, which is in present conditions directed towards urban settlements.

DISCUSSION

The basic branches of hygiene are personal hygiene and collective, or social hygiene. The fields of hygiene are as follows: generative hygiene, hygiene of babies and toddlers, 
school hygiene, nutritive hygiene, mental hygiene, hygiene of work, communal hygiene and environmental hygiene. The problem of communal hygiene in urban and rural areas is comprehenisve and covers all the following factors from this field: water, soil, waste matters, air, climate, pollution of water, soil and air, radiation, communal noise, vibrations, ultrasound, traffic, greenery, environmentally noxious chemicals (which cause diseases), public communal buildings, settlements, habitation, health institutions, schools and nurseries, protection and measures to improve the environment and civil engineering. The aim of research was to roughly determine to what extent certain standards and norms of communal hygiene are present in urban areas of Republic of Srpska. The research was conducted on 300 respondents in Banja Luka, Kneževo, Ribnik, Laktaši, Derventa, Gacko and Kozarska Dubica. The research referred to: I) quality, protection of waters and water supply: II) quality and protection of air and III) hygiene of living and hygiene of schools and nurseries.

Table 1 Age structure of respondents

\begin{tabular}{|l|l|l|l|}
\hline Age groups & $0-19$ & $20-59$ & $60+$ \\
\hline Total & 43 & 188 & 69 \\
\hline$\%$ & 14.33 & 62.67 & 23.0 \\
\hline
\end{tabular}

Table 2 Educational structure of respondents

\begin{tabular}{|l|l|l|l|}
\hline Education & Primary school & Secondary school & University \\
\hline Total & 35 & 207 & 58 \\
\hline$\%$ & 11.67 & 69.0 & 19.33 \\
\hline
\end{tabular}

Table 3 Structure of respondents by industries

\begin{tabular}{|l|l|l|l|l|}
\hline Industry sector & Primary sector & Secondary sector & Tertiary sector & Unemployed \\
\hline Total & 27 & 76 & 112 & 85 \\
\hline$\%$ & 9.0 & 25.33 & 37.33 & 28.33 \\
\hline
\end{tabular}

Table 4 QUESTIONNAIRE - WATER AND WATER SUPPLY

\begin{tabular}{|l|l|l|l|l|l|}
\hline No. & QUESTION & $\begin{array}{l}\text { YES } \\
\%\end{array}$ & $\begin{array}{l}\text { NO } \\
\%\end{array}$ & $\begin{array}{l}\text { Partly } \\
\%\end{array}$ & $\begin{array}{l}\text { I would like to get } \\
\text { informed in more } \\
\text { details (\%) }\end{array}$ \\
\hline $\mathbf{1}$ & $\mathbf{2}$ & $\mathbf{3}$ & $\mathbf{4}$ & $\mathbf{5}$ & $\mathbf{6}$ \\
\hline 1 & $\begin{array}{l}\text { Are you familiar with the standards of water you } \\
\text { use in your household? }\end{array}$ & 3.3 & 36.7 & 53.3 & 10.0 \\
\hline 2 & Do you use city water supply system? & 85.0 & 7.0 & 8.0 & - \\
\hline 3 & Do you use the local water supply system? & 9.8 & 3.0 & 2.2 & - \\
\hline 4 & Do you use water from wells? & 3.0 & - & - & - \\
\hline 5 & $\begin{array}{l}\text { If you use the local water supply or well water, do } \\
\text { you control the water quality on a regular basis? }\end{array}$ & 0.0 & 32.6 & 67.4 & - \\
\hline 6 & $\begin{array}{l}\text { Are you familiar with pathogenic organisms which } \\
\text { can be found in water? }\end{array}$ & 6.4 & 30.3 & 23.7 & 39.6 \\
\hline 7 & $\begin{array}{l}\text { Do you know how potable water disinfection is } \\
\text { done? }\end{array}$ & 35.7 & 19.4 & 24.8 & 20.1 \\
\hline 8 & $\begin{array}{l}\text { Are you familiar with sanitary protection areas in } \\
\text { water supply? }\end{array}$ & 4.7 & 43.8 & 12.6 & 38.9 \\
\hline 9 & $\begin{array}{l}\text { Is there a local inspection of water structures in } \\
\text { your settlement? }\end{array}$ & - & 45.6 & - & 54.4 \\
\hline 10 & $\begin{array}{l}\text { Did you have an appropriate assistance by the local } \\
\text { and entity authorities in dealing with water supply } \\
\text { issues? }\end{array}$ & 31.7 & 23.4 & 28.3 & 16.6 \\
\hline
\end{tabular}


Water and water supply. It can be said that a small percentage of respondents $(3.3 \%)$ is familiar with the quality standards in waters used in households. The answers to questions $2-4$ show that the infrastructural facilities have not been finished yet. That is an expected consequence of a long period of illegal construction, especially in peripheries of towns in Republic of Srpska. The answers to question 5 are worrying as the majority of illegal structures are located in the areas of ground waters which are directly connected with rivers, which are mostly polluted. According to research results (question 7), about 65\% of the respondents are not familiar with the way potable water is disinfected. The water distributed to end users is controlled by the RS Public Health Protection Institute. The control of quality and physical, chemical and bacteriological safety of drinking water is performed pursuant to the RS Water Hygiene Regulations. The number of analyses and parameters is determined pursuant to the aforesaid Regulations. Water chlorination is usually carried out on the pressure pipeline in city water supply (chlorine gas) and is controlled on a daily basis. It is also worrying that almost $95 \%$ of the respondents are not familiar with sanitary protection areas in water supply, while even $100 \%$ of them think there is no local inspection of water facilities. Moreover, it is also worrying that almost $70 \%$ of the respondents are not familiar with how the local and entity authorities can provide assistance in dealing with water supply issues i.e. they are not sure that any assistance has been provided so far.

Table 5 Questionnaire - air

\begin{tabular}{|l|l|l|l|l|l|}
\hline No. & QUESTION & YES & NO & Partly & $\begin{array}{l}\text { I would like to get } \\
\text { informed in more } \\
\text { details (\%) }\end{array}$ \\
\hline $\mathbf{1}$ & $\mathbf{2}$ & $\mathbf{3}$ & $\mathbf{4}$ & $\mathbf{5}$ & $\mathbf{6}$ \\
\hline 1 & $\begin{array}{l}\text { Are you familiar with the influence of climate on } \\
\text { human health? }\end{array}$ & 38.4 & 21.6 & 18.6 & 21.4 \\
\hline 2 & $\begin{array}{l}\text { Are you familiar with the effects of high } \\
\text { temperature? }\end{array}$ & 66.7 & 8.4 & 12.3 & 12.6 \\
\hline 3 & $\begin{array}{l}\text { Are you familiar with the effects of low } \\
\text { temperature? }\end{array}$ & 57.8 & 4.2 & 21.7 & 16.3 \\
\hline 4 & $\begin{array}{l}\text { Are you familiar with the effects of elevated } \\
\text { atmospheric pressure? }\end{array}$ & 33.2 & 19.8 & 43.7 & 3.3 \\
\hline 5 & $\begin{array}{l}\text { Are you familiar with sources of polluting } \\
\text { matters in the air? }\end{array}$ & 42.7 & 13.2 & 36.7 & 7.4 \\
\hline 6 & $\begin{array}{l}\text { Are you familiar with the effects of air pollution } \\
\text { on the human health? }\end{array}$ & 53.4 & 8.7 & 29.4 & 8.5 \\
\hline 7 & $\begin{array}{l}\text { Are conventional energy sources (coal, oil, wood } \\
\text { etc.) mostly used as energy generating products } \\
\text { for heating during the winter? }\end{array}$ & 63.3 & 36.7 & - & - \\
\hline 8 & $\begin{array}{l}\text { Is the smoking ban for public areas complied } \\
\text { with in your local community? }\end{array}$ & 16.7 & 56.7 & 26.6 & - \\
\hline 9 & Are you familiar with global climate changes? & 47.8 & 14.6 & 34.7 & 2.9 \\
\hline 10 & $\begin{array}{l}\text { Are there any unpleasant smells in your local } \\
\text { community? }\end{array}$ & 46.7 & 23.8 & 8.7 & 20.7 \\
\hline
\end{tabular}

Air. Almost $40 \%$ of the respondents believe they are familiar with the influence of climate on people. Regarding the question 2, the respondents mainly know that people feel faintness and exhaustion, whereas they have 'heard' that the existing health problems are more serious with chronic patients, which harms their health. In additional criteria, the respondents actually do not know that the essence of influence of high temperature on the human organism is an increased loss of water and an attempt by the organism to 'cool 
itself down' by widening its blood vessels. The result of these basically physiological processes, which larger population is not very clear with, is a blood pressure drop due to the loss of electrolytes and blood circulation in now widened blood vessels. The answers to the question 3 could be commented on in a similar way. The answers to the question 4 are also indicative. Formal answers (YES, NO, partly etc.) hide the fact that majority of respondents are not familiar with the essence of air pressure change. Sudden changes in air pressure cause airflow, which leads to a change in concentration of ions in the atmosphere. Thus, for instance, during weather 'deterioration' and the occurrence of galeforce winds, such as Foehn wind in the Alps, the concentration of 'killer ions' increases, which results in faintness, headache etc. Regarding air pollution sources, the respondents believe to be familiar with sources of polluters in the air, although they do not state the source of information. The respondents confirm the well-known fact that conventional sources of energy are most frequently used for heating in Republic of Srpska during winter, the reason for which is that, except Banja Luka, a number of urban settlements in Republic of Srpska does not a defined strategy of conversion of conventional energy sources into alternative ones. A ban on smoking on public places (question 8) basically shows our relation to the system of values, while questions 9 and 10 show general awareness of the urban population in Republic of Srpska.

Table 6 Questionnaire - hygiene of living, school and preschool hygiene

\begin{tabular}{|l|l|l|l|l|l|l|}
\hline \multicolumn{7}{|c|}{ Table 6 Questionnaire - hygiene of living, school and preschool hygiene } \\
\hline No. & QUESTION & YES & NO & Partly & $\begin{array}{l}\text { informed like to get } \\
\text { in } \\
\text { more }\end{array}$ \\
\hline $\mathbf{1}$ & $\mathbf{2}$ & $\mathbf{3}$ & $\mathbf{4}$ & $\mathbf{5}$ & $\mathbf{6}$ \\
\hline 1 & $\begin{array}{l}\text { Are the houses/flats in your local community } \\
\text { physiologically functional? }\end{array}$ & 75.2 & 11.4 & 10.8 & 2.6 \\
\hline 2 & $\begin{array}{l}\text { Are there any cases of unhygienic living in your } \\
\text { local community? }\end{array}$ & 39.4 & 32.1 & 11.8 & 16.7 \\
\hline 3 & $\begin{array}{l}\text { Is there an urban plan of your settlement in } \\
\text { relation with hygiene of living? }\end{array}$ & 58.7 & 12.4 & 25.2 & 3.7 \\
\hline 4. & $\begin{array}{l}\text { Do households in your settlement have } \\
\text { homesteads? }\end{array}$ & 14.8 & 56.4 & 16.1 & - \\
\hline 5. & $\begin{array}{l}\text { Have any activities been taken to inform people } \\
\text { in hygiene of living? }\end{array}$ & 2.1 & 76.4 & 18.7 & - \\
\hline 6. & $\begin{array}{l}\text { Is there a primary school in your settlement? } \\
\text { Does the size and type of the school building } \\
\text { comply with standards of hygiene? }\end{array}$ & 54.2 & 23.2 & 22.6 & - \\
\hline 7. & $\begin{array}{l}\text { Is the school connected to the water supply } \\
\text { network? }\end{array}$ & 87.2 & 11.2 & 1.6 & - & - \\
\hline 9. & $\begin{array}{l}\text { Is the classroom furniture, especially classroom } \\
\text { desks, which is the decisive factor in students' } \\
\text { proper posture, suitable to students' age? }\end{array}$ & 32.3 & 9.3 & 58.4 & - \\
\hline 10. & $\begin{array}{l}\text { In your opinion, does the encumbrance of } \\
\text { students with the school curricula correspond to } \\
\text { average physical and intellectual abilities of } \\
\text { children of a certain age? }\end{array}$ & 46.7 & 33.3 & 9.3 & 10.7 \\
\hline
\end{tabular}

Hygiene of living. A dwelling can affect the human health in several ways - whether it facilitates and eases, or prevents and hampers performing a number of functions the dwelling has in human life. Physiologically, a dwelling should enable breathing, thermal regulation, sleep, recreation and sexual functions. Table 6 shows that $75.25 \%$ of the respondents believe that flats and houses in their local community are physiologically 
functional. A minimum of hygienic living implies the sanitary elimination of factors and circumstances which may make a dwelling a morbigenous factor (damp, poor insolation and illumination, presence of allergens etc.). The fact is that about $41 \%$ of the respondents are suspicious about the quality of hygiene of living. It is also confirmed by the fact that no activities have taken place in local communities to inform the population on the hygiene of living (question 5). A part of these results lies in the fact that a good deal of respondents live in suburban and newly built settlements, as a result of migration processes in the period 1992 - 1995. It is evident that a large number of respondents belong to social groups of poor standard of living.

School hygiene. Children spent up to six hours at school, mainly in the sitting position. Therefore, school is not the most favourable environment for physical and mental health of children. The basic goal of school hygiene is to reduce the adverse effect of school environment noxae to a minimum by improving the hygienic and sanitary aspects of school buildings, classrooms, teaching aids and educational regime in accordance with the hygienic standards and requirements $(2,313)$. The main objections to size and type of school buildings refer to the lack of classrooms, gyms with separate dressing rooms, bathroom and washbasins, appropriate toilets with cabins, pantries for cleaning material etc. Many schools have shortage of rooms for activities of students' organisations, extracurricular activities, libraries with reading rooms, school clinics etc. The question is how much water can be provided on a daily basis per student, and the norm is $20-40$ litres. It is evident that almost $68 \%$ of the respondents (question 9) believe that school furniture in unsuitable for students' age. It is well-known that the classroom desk is an important component of school furniture, but also the main cause of some deformities in school students. It is known from school practice that the pressure on students caused by school curricula should correspond to children's physical and intellectual abilities. However, over $50 \%$ of the respondents (question 10) believe that the pressure on school students is not in accordance with their physical or intellectual abilities. These are the answers that should concern us.

\section{CONCLUSION}

Drinking water is water in its natural state or processed water which in terms of its colour, taste, smell, physical, chemical, bacteriological and biological characteristics can be used without hazard to human health. This requires a continual water quality control in line with certain norms. Quality requirements are set out to determine the maximal allowed concentrations, but minimal concentrations are also important in some elements. However, the survey has shown that a high percentage of urban population is not familiar with the basic indicators of drinkable water quality, which implies the need for a complex education of Republic of Srpska population. Polluted air is the air which contains impurities in concentrations higher that the prescribed norms thus significantly affecting the health of people, animals and plants. Ingredients of the atmosphere found in traces in gaseous, liquid or solid state of matter can have a significant influence on the communal hygiene of urban settlements. Some of substances (toxic, radioactive) are harmful to life forms, while traces of matter of different granulometric composition can influence formation of clouds or precipitation intensity but also microclimate change over an urban area. The survey has shown that a part of the respondents are not sufficiently informed on geogenic and anthropogenic mechanisms of formation of particles - polluters. Moreover, the respondents are not familiar with concentrations of these particles in the atmosphere of some urban settlements in Republic of Srpska. 
In choice of locations for those settlements or their parts, urbanisation i.e. development of cities had to take due account of the most suitable terrain. This implies good hygienic properties, which means that the terrain should be drainable, mildly sloped, of a good insolation and abundantly ventilated, the soil should be porous etc. Unfortunately, forced urbanisation in a number of towns in Republic of Srpska ignored many of these minimal requirements. The same situation is with minimal requirements of hygiene of living.

The problem of school hygiene is multiple: school size and type, location of school buildings, classrooms etc. A lot of schools do not have drinking fountains in the corridors. The use of drinking fountains eliminates the use of glasses and other pots, which is very important from epidemiological point of view. In school hygiene, the key factor for a proper students' posture is school furniture, classroom desks in particular. Schools need to have only necessary furniture of such design so that all surfaces can be quickly and easily cleaned. Extracurricular institutions for school students require a separate analysis.

\section{REFERENCES}

[1] Lješević, A., M., Urban Ecology, Faculty of Geography, University of Belgrade, 2002 , pp. $35-37$

[2] Kristoforović - Ilić, M. et al., Communal Hygiene, Prometej, Novi Sad, 1998, pp. 32 - 34 pp. 285 - 287; pp. 313 - 316.

[3] Crnogorac, Č., Spahić, M.,Basics of Geoecology, 'ARTPRINT', Banja Luka, 2012, pp. $99-103$, pp. 163 - 176; pp. $192-195$. 
